Check for updates

New York

Cite this as: BMJ 2020;369:m2616 http://dx.doi.org/10.1136/bmj.m2616 Published: 29 June 2020

\section{Covid-19 cases increase steeply in US south and west}

\author{
Janice Hopkins Tanne
}

Cases of covid-19 are rising sharply in US southern and western states. Of the 50 states, 36 reported increasing cases and only two northeastern states, Connecticut and Rhode Island, reported declining cases.

Cases were increasing in Alabama, Alaska, Arizona, Arkansas, California, Colorado, Florida, Georgia, Hawaii, Idaho, Illinois, Iowa, Kansas, Kentucky, Louisiana, Maine, Michigan, Minnesota, Mississippi, Missouri, Montana, Nevada, New Mexico, North Carolina, Ohio, Oklahoma, Pennsylvania, South Carolina, Tennessee, Texas, Utah, Vermont, Washington, West Virginia, Wisconsin, and Wyoming. In other states cases were remaining steady.

On 26 June there were nearly 46 ooo new cases, the highest daily increase reported so far. The US now has the highest number of covid-19 infections in the world-more than 2.5 million cases and more than 125000 deaths, as of 29 June. $^{1}$

The actual number of infections is probably 10 times higher, or 20 to 25 million cases, said Robert Redfield, director of the Centers for Disease Control and Prevention (CDC), at a press briefing last week. Many of the people infected might be younger and asymptomatic but able to spread the infection, he said. ${ }^{2}$

President Donald Trump said that the US was making great progress, and vice president Mike Pence said at a press briefing on 26 June that the US had "flattened the curve" of virus cases.

More than 90\% of Americans have not been infected and remain susceptible, Redfield said. The most important tools for avoiding infection are social distancing, wearing face masks in public, and frequent hand washing, he said. He also said that the CDC was working to help states with contact tracing, which so far had had limited success.

Despite the increase in covid-19 cases, the Trump administration asked the Supreme Court in a brief submitted near the midnight deadline last on 25 June to invalidate the Affordable Care Act, known as Obamacare. It provides health insurance to about 23 million Americans, guarantees health insurance for those with pre-existing conditions, and allows young people under 26 to be covered under their parents' health plans. Some of the nine million Americans who have lost their job related health insurance are signing up for coverage under the act. ${ }^{3}$

During his 2016 presidential campaign President Trump promised to repeal Obamacare and replace it with something better. Several attempts to repeal it have failed and no plan to replace it has been presented, although Alex Azar, secretary of Health and Human Services, said that his department was working on a plan. The court probably will not decide on the case until after the 3 November election.

Increased testing is the reason for the increase in covid-19 cases, according to Trump, Pence, and Azar. The president even suggested slowing testing so the number of cases would not increase.

Public health experts such as Thomas Frieden, former head of the CDC, disagreed. On Fox News Sunday, Frieden said, "As a doctor, scientist, an epidemiologist, I can tell you with $100 \%$ certainty that in most states where you're seeing an increase, it is a real increase. It is not more tests, it is more spread of the virus." He said the rise was real, indicated by the percentage of tests that were positive. ${ }^{4}$

Positivity rates range from $0.59 \%$ in Alaska and 1.09\% in New York, which seems to have overcome the nation's worst covid-19 outbreak, to $22.64 \%$ in Arizona, $14.4 \%$ in Florida, and $13.7 \%$ in Texas. The World Health Organization recommends that positivity rates remain below $5 \%$ for at least 14 days. ${ }^{5}$

The increase has been blamed on socialisation over the long Memorial Day weekend in late May and to reopening of states, which relaxed rules for gatherings and for shops, bars, restaurants, and (in Nevada) casinos.

Most of these states reopened early. Governor Greg Abbott of Texas has now ordered bars to close and restaurants to limit indoor seating. Florida governor Ron DeSantis ordered bars to stop serving alcohol and closed Miami's beaches for the coming 4 July weekend. Neither governor has required mask wearing.

Governor Gavin Newsom of California ordered bars to be closed in seven counties. Governor Jay Inslee of Washington State said on Face the Nation that he was frustrated that Trump did not wear a mask or encourage people to do so. "Instead of tweeting the other day about the importance of masks, he tweeted about monuments. We need a president who will care more about living Americans and less about dead Confederates," he said, referring to the move to remove statues of generals who fought for the Confederacy in the American Civil War. 6 
Trump has indicated that he will continue holding campaign rallies, even though the first, in Tulsa, Oklahoma, was sparsely attended because of fears of contracting the virus. Pence cancelled election campaign rallies in Arizona and Florida this week, although he will visit the states to meet local officials.

1 Covid-19 Dashboard for the Center for Systems Science and Engineering at Johns Hopkins University (JHU). https://gisanddata.maps.arcgis.com/apps/opsdashboard/index.html\#/bda7594740fd40299423467b48e9ecf6

2 Transcript for the CDC Telebriefing Update on Covid-19. June 25, 2019. www.cdc.gov/media/releases/2020/t0625-COVID-19-update.html

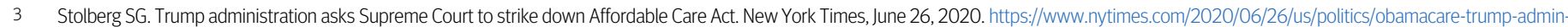
istration-supreme-court.html

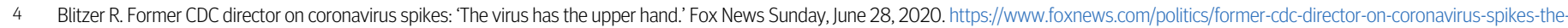
virus-has-the-upper-hand

5 Johns Hopkins University Coronavirus Resource Center. Testing Hub. Which US states meet WHO recommended testing criteria? https://coronavirus.jhu.edu/testing/testing-positivity

6 Coronavirus live updates: Global tally of known cases passes 10 million. New York Times, June 28, 2020. www.nytimes.com/2020/06/28/world/coronavirus-updates.html

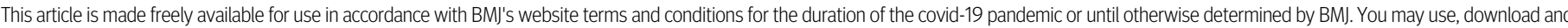
print the article for any lawful, non-commercial purpose (including text and data mining) provided that all copyright notices and trade marks are retained. 